\title{
LEPIDOPTERA DAN PARASITOID YANG BERASOSIASI PADA TANAMAN KENANGA (CANANGA ODORATA (LAM.) HOOK.F. \& THOMSON)
}

\section{ASSOCIATION OF LEPIDOPTERA AND PARASITOID ON CANANGA ODORATA (LAM.) HOOK.F. \& THOMSON}

\author{
M. Kamilah Himawati dan Retno Wijayanti \\ Jurusan Agroteknologi Fakultas Pertanian Universitas Sebelas Maret
}

\begin{abstract}
ABSTRAK
Tujuan penelitian ini adalah untuk mengidentifikasi Lepidoptera dan parasitoid bahwa berasosiasi pada C. odorata . Penelitian dilakukan di Laboratorium Hama dan Penyakit Fakultas Pertanian UNS dan di lapangan lokasi penanaman di Banyudono, Kabupaten Boyolali, Jawa Tengah. Pengamatan dilakukan dari hasil semaian bibit tanaman Kenanga. Lepidopteran (larvae, pupae, dewasa) dan parasitoids yang diambil dan diidentifikasi di laboratorium. Larva dan pupa yang terjangkit oleh parasitoid atau pathogen dipisahkan dan dipelihara untuk menunggu parasitoid memuncul. Koleksi dari Lepidopteras dan parasitoids diidentifikasi dengan membandingkan gambar diterminasi. Identifikasi dilakukan pada beberapa jenis yang ditemukan. Pada penelitian ini ditemukan delapan jenis dari Lepidopteras dan dua parasitoids. Delapan jenis dari Lepidopteras terdiri dari jenis dari Lymantridae keluarga, Nymphalidae, Papilionidae, Satyridae, Psychidae, dan Saturniidae (Cricula trifenestrata dan Atlas Attacus). Dua parasitoid adalah Apanteles sp. dan Pteromalus sp.)
\end{abstract}

Kata kunci : Lepidopteran, Parasitoid , Canangan odorata, Lymantridae, Nymphalidae, Papilionidae, Satyridae, Psychidae, Cricula trifenestrata, Atlas Attacus, Apanteles sp ., Pteromalus sp.

\begin{abstract}
The objectives of this research are to identify the Lepidoptera and parasitoid that associated on C. odorata. The research was conducted in Laboratory of Pest and Disease of Crop of Agriculture Faculty UNS and in C. odorata plantation in Banyudono, Boyolali Regency, Central Java. Observation was done at seedling and crop yield. Lepidoptera (larvae, pupae, adult) and parasitoids that found were taken to be identified in laboratory. Larvae and pupae which infected by parasitoid or pathogen placed in separated jar to be kept and waited for parasitoid emerged. Collection of Lepidopteras and parasitoids were identified by comparing with picture, using key of determination, and combination both of them. Identifying was done at family and several of them at species.In this research was found eight species of Lepidopteras and two parasitoids. Eight species of Lepidopteras consist of species of family Lymantridae, Nymphalidae, Papilionidae, Satyridae, Psychidae, and Saturniidae ( Cricula trifenestrata and Attacus atlas). Two parasitoid were Apanteles sp. and Pteromalus sp.)
\end{abstract}

Key words : Lepidoptera, Parasitoid, Canangan odorata, Lymantridae, Nymphalidae, Papilionidae, Satyridae, Psychidae, Cricula trifenestrata, Attacus atlas, Apanteles sp., Pteromalus sp.

\section{PENDAHULUAN}

Tanaman kenanga (Fam: Annonaceae , parfume tree, Cananga odorata) termasuk tanaman liar yang saat ini keberadaannya sudah mulai berkurang.. Kenanga dapat tumbuh dengan baik di daerah dataran rendah dengan ketinggian 25 -1000 meter di atas permukaan laut (Hobir et el., 1990). Salah satu sentra pertanaman kenanga di Jawa Tengah adalah di Kabupaten Boyolali yaitu di Desa Banyudono.

Ulat daun (larva Lepidoptera) merupakan salah satu hama penting yang menyerang daun kenanga. Ada berbagai macam spesies yang menyerang tanaman kenanga dan larva tersebut memiliki potensi merusak yang sangat tinggi. Para petani melaporkan bahwa ulat-ulat tersebut dapat menyerang tanaman kenanga sepanjang tahun baik pada musim kemarau maupun musim 
penghujan, meskipun intensitas serangan tertinggi terjadi pada akhir musim kemarau hingga awal musim penghujan. Ulat-ulat menyerang tanaman sejak di pembibitan hingga pada tanaman yang sudah menghasilkan bunga.

Sampai saat ini tindakan pengendalian ulat daun kenanga oleh petani masih sangat minim, petani hanya membiarkan saja serangan ulat tersebut, meskipun akhirnya petani merasa dirugikan. Hal ini disebabkan oleh sulitnya praktik pengendalian karena serangan ulat sering terjadi pada pohon-pohon yang sudah tinggi.

Masih sangat langka informasi mengenai musuh alami yang menyerang ulat daun kenanga, meskipun keberadaannya ada di lapangan. Musuh alami tersebut sangat potensial untuk dikembangkan menjadi agens pengendalian hayati, terutama parasitoid dan entomopatogen.

Pengembangan musuh alami untuk menjadi agens pengendalian hayati (APH) sangat membutuhkan informasi mengenai spesies hama maupun musuh alaminya secara tepat, karena pengendalian secara hayati bersifat sangat spesifik. Oleh karena itu dibutuhkan identifikasi yang tepat mengenai jenis spesies hama maupun musuh alaminya.

\section{BAHAN DAN METODE}

Pengamatan di lapangan dilakukan pada lahan pertanaman kenanga milik petani di Desa Banyudono, Kabupaten Boyolali, Jawa Tengah. Pengamatan dilakukan tiga kali dengan interval pengamatan 1 bulan. Waktu penelitian mulai bulan Mei hingga bulan Oktober 2009.

Pengamatan dilakukan pada pembibitan dan pada tanaman yang sudah menghasilkan (berproduksi). Serangga Lepidoptera (larva, pupa, imago) yang ditemukan pada tanaman kenanga diambil untuk diidentifikasi di laboratorium, begitu juga musuh alaminya. Ulat dan pupa yang menunjukkan gejala terserang parasitoid atau patogen ditempatkan pada wadah tersendiri untuk dipelihara dan ditunggu kemunculan musuh alaminya.

Serangga Lepidoptera dan musuh alami hasil koleksi diidentifikasi dengan cara membandingkan dengan gambar, menggunakan kunci determinasi dan kombinasi dari keduanya. Identifikasi dilakukan sampai tingkat famili dan beberapa sampai tingkat jenis (spesies).

\section{HASIL DAN PEMBAHASAN}

Dari hasil penelitian, diperoleh delapan jenis Lepidoptera yang menyerang tanaman kenanga. Musuh alami yang berupa parasitoid ada dua jenis, sedangkan entomopathogen tidak ditemukan. Delapan jenis Lepidoptera yang ditemukan adalah :

\section{Anggota famili Lymantriidae}

Ada dua jenis Lepidoptera dari anggota Lymantridae yang ditemukan menyerang tanaman kenanga. Kedua jenis Lepidoptera ini menyerang pada bagian daun. Kedua jenis ini baru dapat diidentifikasi sampai tingkat famili. Kedua jenis serangga tersebut adalah jenis a (Gambar 1) dan jenis b (Gambar 2).

Larva/ulat dari anggota Lymantriidae mempunyai rambut/bulu yang tebal (rumbai) pada bagian dorsal, pada segmen kedua terdapat empat bulu yang menebal dan panjang (bulu pensil) (Kalshoven, 1981; Division of Entomology Commonwealth Scientific and Industrian Research Organization, 1991)

Larva mempunyai kisaran inang yang luas (polifag). Pupasi terjadi di dalam cocon yang terbuat dari jaringan, rambut, maupun bulubulunya. Akibat serangan ulat ini daun-daun kenanga meranggas dan biasanya menyebabkan tanaman menjadi gundul. Akibat dari keadaan ini bunga kenanga jumlahnya menjadi berkurang dan biasanya stadia pembungaan mengalami kemunduran. Serangan ulat jenis a dapat terjadi sepanjang tahun, baik pada musim penghujan maupun kemarau, sedang ulat jenis b biasanya menjadi masalah pada saat musim hujan (sekitar bulan Januari-Februari).

Ulat jenis a telurnya diletakkan oleh dewasanya secara tunggal dalam kelompok, setiap kelompok telur terdiri dari lebih 80 butir telur (Gambar 1a). Pada saat diletakkan berwarna kekuningan dan menjelang menetas berwarna abu-abu kehitaman. Ulat yang baru menetas hingga instar 2-3 mengelompok dan bersifat gregarius dalam pintalan benang yang terbuat dari air liurnya (Gambar 1b). Ulat dewasa akan saling memisahkan diri dan hidup secara soliter (Gambar 1c,d). Ulat ini menyerang tanaman kenanga sejak di pembibitan hingga pada tanaman dewasa yang telah menghasilkan bunga. 

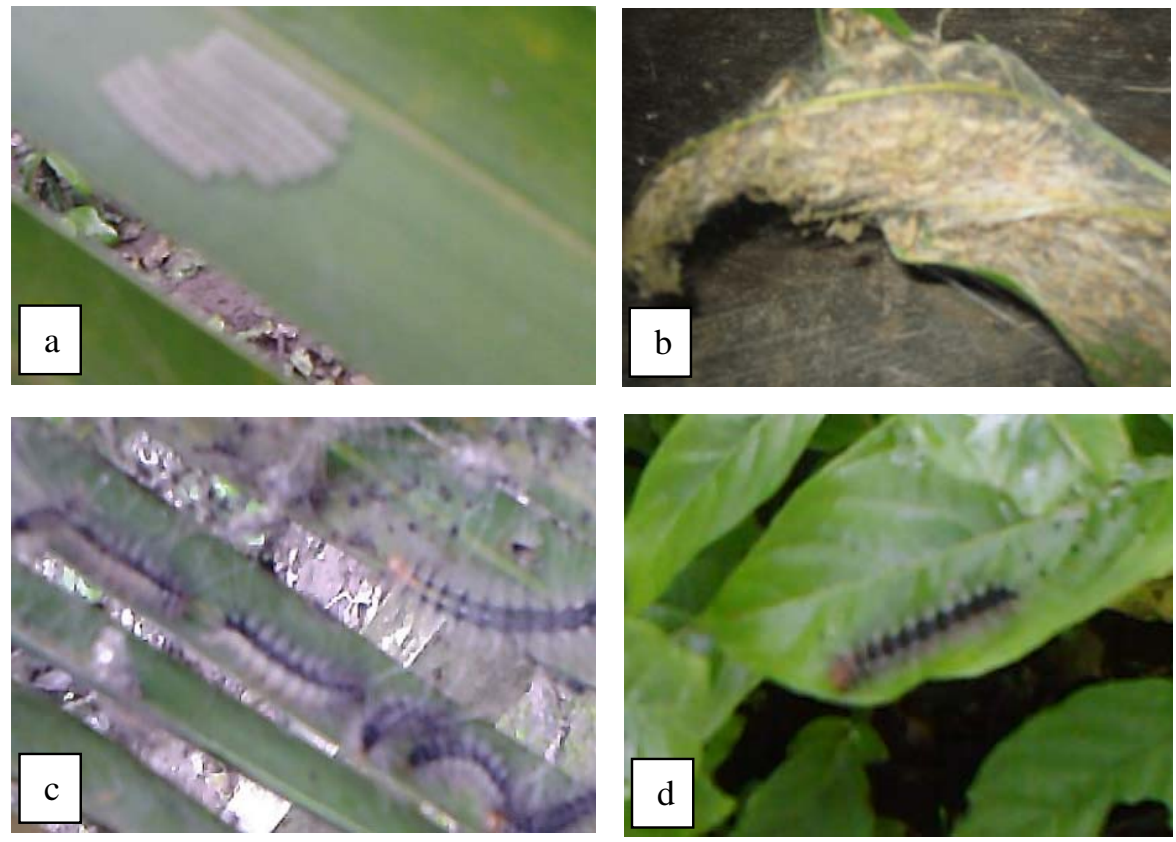

Gambar 1. Ulat anggota famili Lymantriidae jenis a a. Kelompok telur, b. Ulat instar awal (gregarius), c dan d. Ulat instar lanjut (soliter)
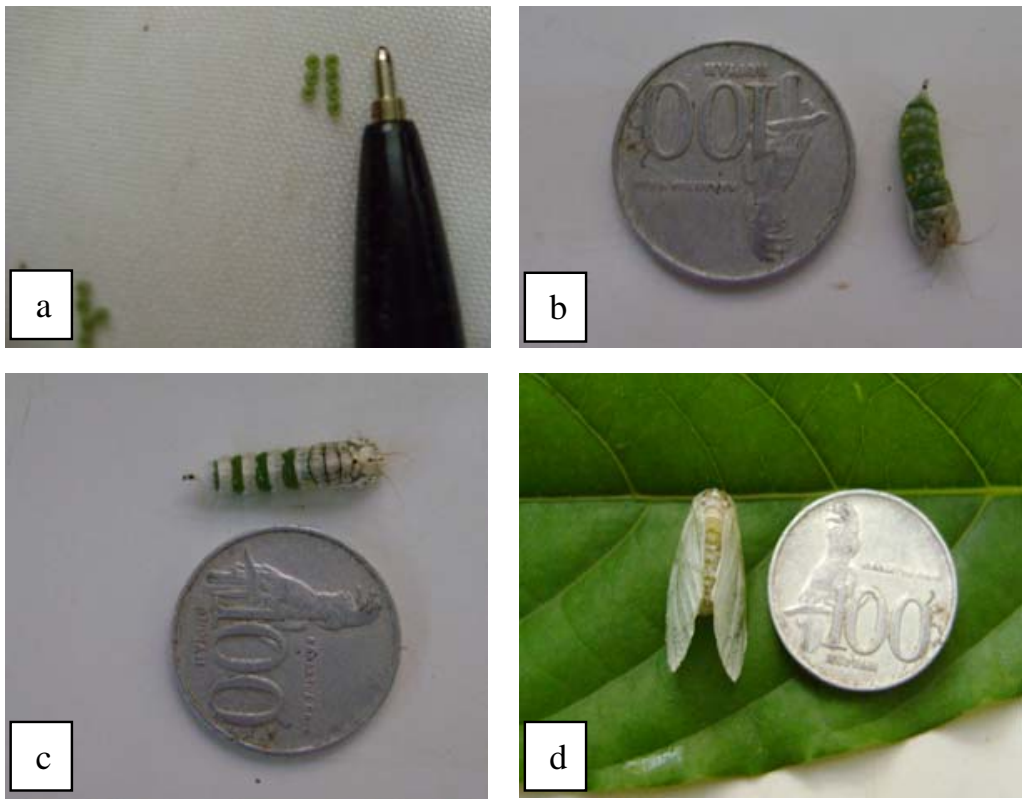

Gambar 2. Ulat anggota famili Lymantriidae jenis b a. Kelompok telur, b. Pupa muda, c. Pupa tua, d. Imago 


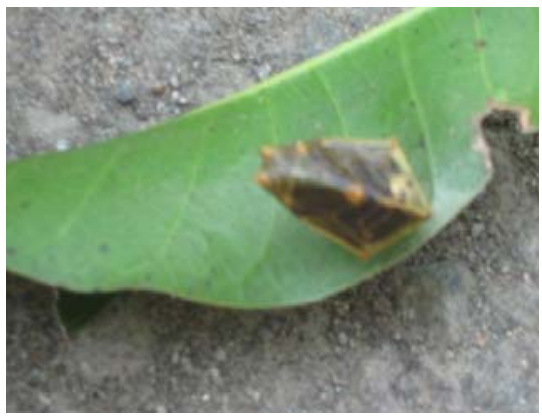

Gambar 3. Pupa Nymphalidae

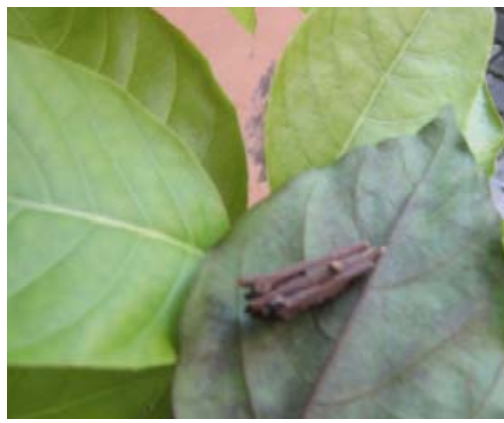

Gambar 6. Ulat kantung

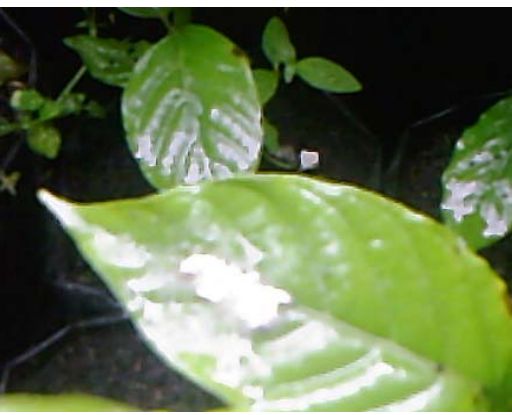

Gambar 9. Ulat Lymantriidae terparasit oleh Apanteles trifenestrata

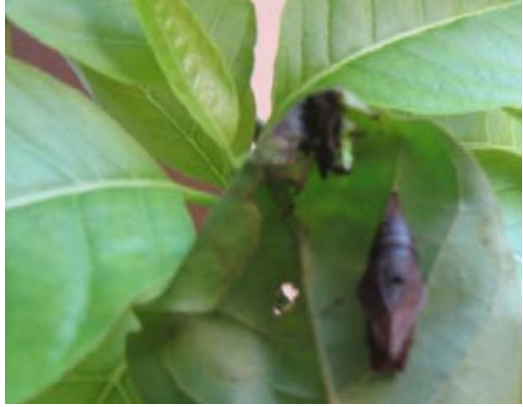

Gambar 4. Pupa Papilionidae

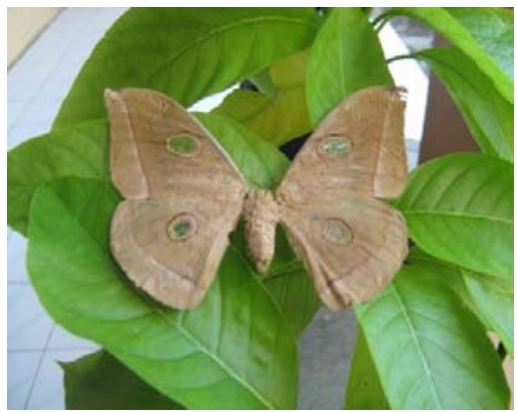

Gambar 7. Ngengat Cricula
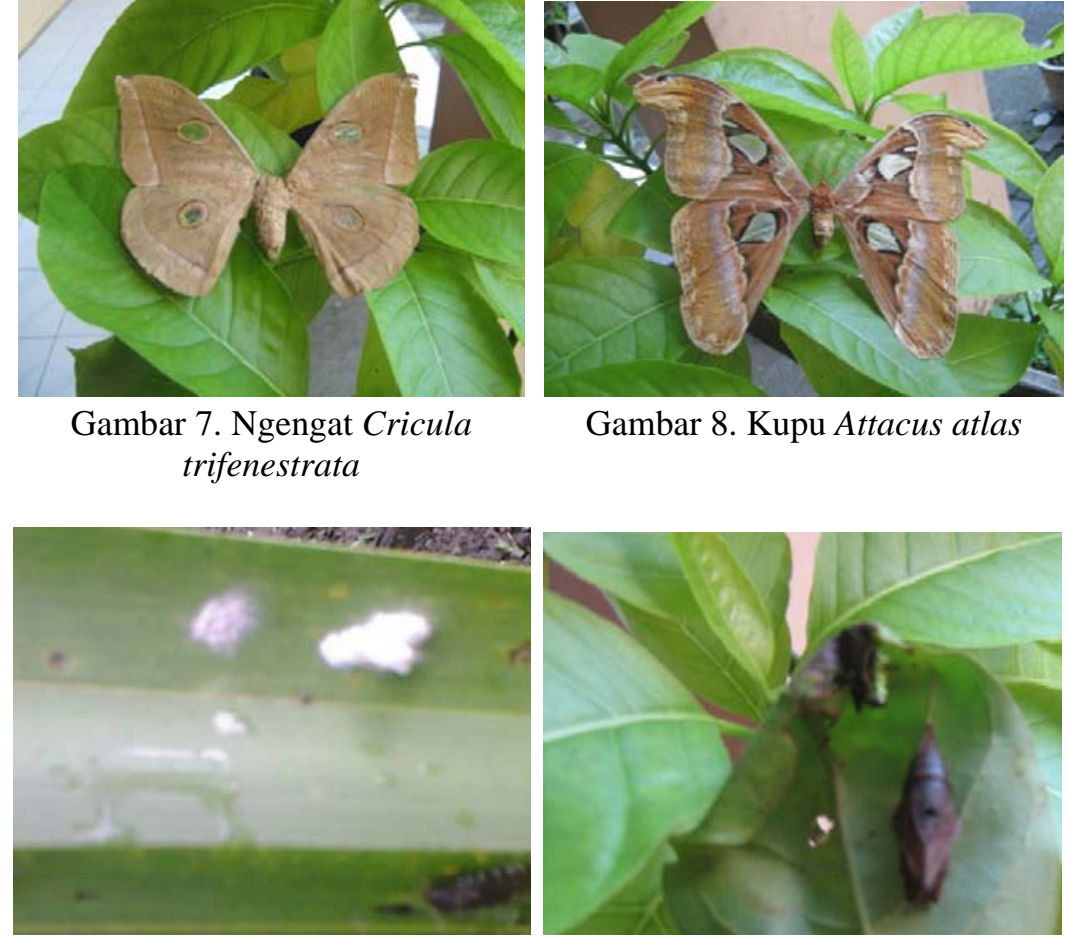

Gambar 8. Kupu Attacus atlas

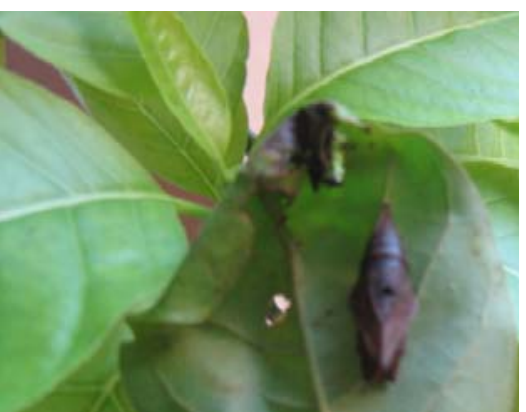

Gambar 10. Pupa Papilionidae terparasid oleh Pteromalus sp.
Ulat jenis b, telurnya juga diletakkan dalam kelompok tetapi tiap kelompok telur jumlahnya lebih sedikit (sekitar 30). Telur pada saat diletakkan berwarna hijau dan berubah menjadi kecoklatan menjelang menetas (Gambar 2a). Ulat berwarna hijau cerah. Stadia ulat berlangsung selama 8-10 hari. Pada saat terbentuk pupa berwarna hijau (Gambar 2b) dan menjelang muncul imago pupa akan berubah warna menjadi coklat dan ada garis melintang berwarna hitam (Gambar 2c). Pupa berlangsung selama \pm 5-7 hari. Imago/kupu yang muncul berwarna putih agak kekuningan dengan panjang sekitar $20 \mathrm{~mm}$ (Gambar 2d).

\section{Anggota famili Nymphalidae}

Lepidoptera anggota famili dari Nymphalidae yang ditemukan pada saat pengamatan adalah stadium pupa/kepompong.
Pupa dari famili Nymphalide bentuknya khas yaitu seperti laying-layang (Gambar 3). Pupa tidak mempunyai cremaster (alat tambahan pada bagian ujung abdomen). Pupa menggantung di daun pada bagian kepalanya.

Ulat ini mempunyai inang yang luas (polifag) yaitu tanaman semak, rumput, dan pohon-pohon dari berbagai famili tetapi mayoritas pada tanaman dicotyl (Kalshoven, 1981). Serangan ulat ini tidak menyebabkan kerugian yang berarti, karena biasanya populasinya tidak besar.

\section{Anggota famili Papilionidae}

Lepidoptera anggota famili dari Papilionidae yang ditemukan pada saat pengamatan adalah stadium pupa/kepompong. Menurut Division of Entomology Commonwealth Scientific and Industrian Research Organization ( 
1991) pupa dari famili Papilionidae berbentuk eksposit (memanjang). Pada cremaster terdapat bantalan sutera yang berguna untuk melekatkan tubuh pada dahan atau daun. Pada bagian atas (thorax dekat kepala) menggantung dengan benang yang dilekatkan pada dahan/ranting (Gambar 4).

Ulat ini mempunyai inang yang tidak luas hanya dalam famili tertentu (kalshoven, 1981). Serangan ulat ini tidak menyebabkan kerugian yang berarti, karena biasanya populasinya tidak besar dan di alam terdapat parasitoidnya yaitu Pteromalus sp.

\section{Anggota famili Satyridae}

Ulat anggota famili Satyridae ini selain menyerang kenanga, juga hidup di rumput dan tanaman dari famili Palmae. Ulat aktif pada malam hari. Pupa mempunyai bentuk yang khas, yaitu ada tonjolan pada bagian kepalanya. Pupa menggantung bebas pada daun dengan pelekatan pada bagian abdomen (Gambar 5). Kupu bersifat dimorfisme pada musim yang berbeda. Ulat dari anggota famili Styridae ini bukan merupakan hama utama pada tanaman kenanga.

\section{Anggota famili Psychidae}

Ulat anggota famili Psychidae sering disebut dengan ulat kantung/bag moth (Gambar 6). Ulat berada di dalam kantung hingga stadia dewasa. Bentuk kantung sangat bervariasi. Ukuran kantung akan bertambah besar seiring pertumbuhan ulat. Ulat makan dengan cara mengeluarkan bagian kepala hingga torak segmen pertama dari lubang kantung. Ulat bersifat polifagus, tapi lebih menyukai tanaman berkayu (pohon) yang tua.

\section{Anggota famili Saturniidae}

Ada dua spesies yang ditemukan menyerang kenanga yaitu Cricula trifenestrata dan Attacus atlas. Ulat C. trifenestrata berwarna hitam dengan spot dan rambut-rambut berwarna putih. Kepala dan abdomen berwarna merah gelap. Panjang larva bisa mencapai $60 \mathrm{~mm}$. Pupa terbungkus benang sutera berwarna keemasan. Ulat mempunyai kisaran inang yang luas. Selain di kenanga, ulat juga banyak dijumpai menyerang tanaman alpukat, kedomdong, cacao, jambu, dll. (Kalshoven, 1981). Rentang sayap ngengat betina mencapai 75 mm (Gambar 7). Ngengat bukan penerbang yang baik dan aktif pada malam hari.

A. atlas sering disebut dengan kupu gajah karena ukurannya yang besar dan tanda-tanda yang atraktif (Gambar 8). Ulat A. atlas bentuknya khas, panjang lebih dari $150 \mathrm{~mm}$, berwarna hijau dan diselimuti dengan tepung putih. Ulat $A$. atlas mempunyai inang yang luas. Selain pada tanaman kenanga, ulat $A$. atlas sering juga dijumpai di tanaman mangga, alpukat, sirsak, dll (Kalshoven,
1981). Pupanya terbungkus cocon yang kuat dan berwarna coklat.

\section{Dua jenis parasitoid yang ditemukan adalah : Apanteles sp.}

Apanteles (Hymenoptera : Braconidae) adalah musuh alami yang berupa parasitoid larva. Parasitoid ini mempunyai kisaran inang yang luas, antara lain Plusia chalcites, Crocidolomia binatalis, Attacuc atlas, dan Spodoptera litura.

Apanteles dewasa berukuran sangat kecil, panjangnya sekitar 2-3 mm. Apanteles betina meletakkan telur ke dalam tubuh inang (pada stadium telur atau larva instar awal) dengan ovipositornya, biasanya dalam satu inang akan diletakkan telur sebanyak 16-65 butir. Telur-telur tersebutakan menetas dalam 2-3 hari, dan larva yang muncul akan segera memakan tubuh inangnya dari dalam (endoparasitoid). Menjelang berpupa, larva akan keluar dari tubuh inang dan berpupa di luar tubuh inang. Pupa Apanteles berwarna putih. Dewasa yang muncul hanya hidup beberapa hari saja. Apanteles yang ditemukan pada saat penelitian menyerang ulat dari anggota Famili Lymantriidae jenis a (Gambar 9).

\section{Pteromalus sp.}

Pteromalus puparum (L.) (Hymenoptera : Pteromalidae) adalah endoparasitoid pupa Lepidoptera. Pada saat survai parasitoid Pteromalus ditemukan menyerang/ memarasit pupa Papilionidae (Gambar 10). Pteromalus dewasa berukuran sangat kecil kurang lebih hanya 3-4 mm. Pteromalus dewasa meletakkan telurtelurnya ke dalam tubuh inang pada saat stadia pra pupa atau pupa yang baru terbentuk. Selama hidupnya Pteromalus dewasa mampu meletakkan telurnya hingga 700 butir dan setiap pupa rata-rata ada 200 telur.

\section{KESIMPULAN}

1. Lepidoptera yang ditemukan menyerang tanaman kenanga ada delapan jenis yaitu dua jenis dari famili Lymantridae, satu jenis dari Nymphalidae, Papilionidae, Satyridae, dan Psychidae, serta dua jenis dari famili Saturniidae (Cricula trifenestrata dan Attacus atlas)

2. Musuh alami yang ditemukan adalah dari golongan parasitoid yaitu Apanteles sp. yang menyerang ulat dari anggota famili Lymantridae dan Pteromalus sp. yang menyerang ulat dari anggota famili Papilionidae. 


\section{DAFTAR PUSTAKA}

Borror, D.J. dan R.E. White, 1970. A Field Guide to The Insect. Houghton Mifflin Company. Boston

CPP (Crop Protection Compendium), edisi kedua.

Division of Entomology Commonwealth Scientific and Industrian Research Organization, 1991. The Insect of Australia. Scond Edition. Melbourne University Press. Vol II.

Goulet, H. dan J.T. Huber, 1993. Hymenoptera of The World : An Identification Guide to Families. Research Branch Agriculture. Canada.

Hobir. 1989. Budidaya Ylang-ylang. Balai Penelitian Tanaman Rempah dan Obat. Bogor.

Hobir, 1990. Kenanga dan Ylang-ylang. Bull. Littro. 4 (1): 30-37.

Kalshoven, L.G.E., 1981. Pest of Crop in Indonesia. Revisid and Translated by P.A. Van Der Laan. P.T. Ichtiar Baru- Van Hoeve. Jakarta.
Poinar G.O. dan G.M. Thomas, 1982. Diagnostic Manual fot The Identification of Insect Pathogen. Plenum Press. New York and London.

Subyanto dan A. Sulthoni, 1980. Kunci Determinasi Serangga. Fakultas kehutanan UGM. Yogyakarta. 39 p.

Yasin, M., Masmawati, dan D. Baco, 1997. Peranan Parasitoid Telur Wereng Cokelat Nilaparvata lugens Stal., di persawahan maros, Sulawesi Selatan. Prosiding Makalah Pendukung Seminar Nasional Pengendalian Hayati terpadu. 25-26 November 1996. Yogyakarta. Pusat Studi Pengendalian Hayati UGM. P. 33-36.

\section{UCAPAN TERIMAKASIH}

Ucapan terimakasih penulis sampaikan kepada pemberi dana penelitian, yaitu DIPA PNBP LPPM Tahun Anggaran 2009 Fakultas Pertanian Universitas Sebelas Maret. 